\title{
The Fatty Acid and Sterol Content of Food Composites of Middle-Aged Men in Seven Countries
}

\author{
Jeanne H. M. de Vries, ${ }^{*}$ Annemarie Jansen, $\dagger$ Daan Kromhout, $\dagger$ \\ Peter van de Bovenkamp,* Wija A. van Staveren,* \\ Ronald P. Mensink, $\neq$ and Martijn B. Katan*,1 \\ For the Seven Countries Study Group
}

\begin{abstract}
*Department of Human Nutrition, Wageningen Agricultural University, 6703 HD Wageningen, the Netherlands; ${ }^{\dagger}$ National Institute of Public Health and the Environment, 3721 MA Bilthoven, the Netherlands; and $\ddagger$ Department of Human Biology, University of Limburg, 6200 MD Maastricht, the Netherlands
\end{abstract}

Received December 29, 1995, and in revised form December 12, 1996

\begin{abstract}
Specific fatty acids and sterols in food composites from seven countries were analyzed. In the 1960s, groups of 8 to 49 men from 16 cohorts, ages 40-59 years and living in the United States, Finland, the Netherlands, Italy, Greece, the former Yugoslavia, or Japan recorded their food intake. In 1987, we collected food composites representing the average food intake per cohort sample in the 1960s. The foods were transported to the Netherlands, pooled, and centrally analyzed for energy, total fat, 42 fatty acids, cholesterol, and four plant sterols. The fat content ranged from $12 \%$ of total daily energy in the Tanushimaru, Japan, cohort to $50 \%$ in the U.S. cohort sample, and the polyunsaturated to saturated fat ratio ranged from 0.17 in the east Finland cohort to 1.2 in Tanushimaru. The amount of trans fatty acids with 16 or 18 carbon atoms varied between $0.2 \mathrm{~g} /$ day in Corfu, Greece, and $8.6 \mathrm{~g} /$ day in Zutphen, Netherlands, and that of $\alpha$-linolenic acid between $0.8 \mathrm{~g} /$ day in Rome and $2.5 \mathrm{~g} /$ day in east Finland. The sum of eicosapentaenoic and docosahexanoic acid ranged from 0.1 (U.S. railroad) to $2.0 \mathrm{~g} /$ day (Ushibuka, Japan), and phytosterols from 170 (U.S. railroad) to $358 \mathrm{mg} / \mathrm{day}$ (Corfu, Greece). Thus the intake of various fatty acids and sterols with potential relevance for coronary heart disease occurrence varied 10-fold or more between cohorts. Our data can be used to generate new hypotheses about the causes of differences in incidence of diseases between countries. @ 1997 Academic Press
\end{abstract}

\section{INTRODUCTION}

Fatty acids and sterols in the diet play a major role in the etiology of coronary heart disease (Willett and Sacks, 1991). Therefore, it is important to know the amounts and types of fatty acids and sterols that are present in the diets of populations, and to know which foods are the main contributors. However, food tables lack reliable data on the content of specific fatty acids, such as trans fatty acids (Litin and Sacks, 1993), long-chain polyunsaturated ( $n$-3) fatty acids, and plant sterols. As a consequence, the content of these nutrients in diets cannot be calculated from food balance sheets or dietary surveys, using nutrient data bases.

At the end of the 1950s, the Seven Countries Study was designed to study the

${ }^{1}$ To whom reprint requests should be addressed at the Department of Human Nutrition, Wageningen Agricultural University, Bomenweg 2, 6703 HD Wageningen, The Netherlands. Fax: +31 317483342 . E-mail: Jeanne.deVries@et2.voed.wau.nl. 
relationships between diet and the occurrence of chronic diseases (Keys, 1980). The food intake was recorded at that time by random samples of men, ages 40-59 years, who were part of a total of 16 cohorts in the United States, Finland, the Netherlands, Greece, Italy, the former Yugoslavia, and Japan. Duplicate portions were collected in 1960, and protein, total fat, and overall fatty acid composition were analyzed. However, a large number of nutrients and other components in the diet which could be important with regard to the occurrence of diseases were not determined. In 1987 we therefore decided to sample equivalent food composites, representing the average reported food intake of the men in the 1960s (Den Hartog et al., 1968; Keys, 1970), and to analyze these chemically for a large number of nutrients and nonnutrients.

One of our aims was to obtain detailed information on the fatty acid and sterol composition of the diets, and we therefore determined the mean content of 42 fatty acids and four sterols in the collected food composites in a central laboratory. We present here the results of these chemical analyses, which can be used to investigate relationships between the composition of diets in the 1960s and the disease outcome in later years.

\section{METHODS}

\section{Subjects}

Sixteen groups each containing 502 to 2571 men, ages $40-59$ years, were selected in the seven countries. Random samples of 8 to 49 men in each cohort (Table 1) recorded their food intake, mostly during 7 days at the baseline survey in the 1960s (Den Hartog et al., 1968; Keys, 1970; Kromhout et al., 1989).

The U.S. participants were railroad employees. One Finnish cohort lived in east Finland, and the other in west Finland. In the Netherlands men living in the commercial town of Zutphen, in the eastern part of the country, participated. Italy contributed three cohorts: Montegiorgio and Crevalcore, both rural villages, and railroad personnel in Rome. Greece contributed two: one on Crete and one on the island of Corfu. Five cohorts were from the former Yugoslavia: two from Croatia included inhabitants of six towns on the Dalmatian Coast and of Dalj, a small town in Slavonia. The other three cohorts consisted of farmers from the village of Velika-Krsna, workers in a large cooperation in Zrenjanin, and university professors in Belgrade in Serbia. Japan had two cohorts: farmers from the village of Tanushimaru and fishermen from the village of Ushibuka.

\section{Food Records}

Between 1959 and 1964 samples of participants from 13 cohorts recorded and weighed all they ate and drank for 7 days and a sample of U.S. railroad employees did the same for 1 day. The participants from Rome recorded their food intake in 1969 for 7 days and those from Ushibuka in 1971 for 4 days. Thirteen cohorts reported the foods as weight of edible parts of raw products, and 3 cohorts as prepared foods. The 2 Greek cohorts recorded their intakes in different seasons. As the original 7-day records of the Greek cohorts were no longer available, we reconstructed the diets using a publication of Keys (1970), and information provided by the Greek dietician involved in the original study. We derived missing information on some foods, espe- 
TABLE 1

Characteristics of Food Records Reported by Men Ages 40 to 59 Years IN 16 Cohorts in Seven Countries IN THE 1960s

\begin{tabular}{|c|c|c|c|c|}
\hline Cohort & Country & Year & $\begin{array}{l}\text { Number of } \\
\text { subjects }\end{array}$ & $\begin{array}{l}\text { Number of } \\
\text { recording days }\end{array}$ \\
\hline US railroad & United States & $1960-62$ & 30 & 1 \\
\hline East-Finland $^{\mathrm{a}}$ & Finland & 1959 & 30 & 7 \\
\hline West-Finland $^{a}$ & Finland & 1959 & 30 & 7 \\
\hline Zutphen & Netherlands & 1960 & 45 & 7 \\
\hline Crevalcore $^{a}$ & Italy & 1960 & 29 & 7 \\
\hline Montegiorgio ${ }^{a}$ & Italy & 1960 & 35 & 7 \\
\hline Rome railroad & Italy & 1969 & 49 & 7 \\
\hline Corfu $^{\mathrm{ab}}$ & Greece & $1961-63$ & 37 & 7 \\
\hline Crete $^{a b}$ & Greece & $1960-65$ & 31 & 7 \\
\hline Dalmatia & Croatia & 1960 & 24 & 7 \\
\hline Slavonia ${ }^{a}$ & Croatia & 1960 & 24 & 7 \\
\hline Belgrade $^{a}$ & Serbia & 1964 & 41 & 7 \\
\hline Velika-Krsna ${ }^{a}$ & Serbia & 1963 & 21 & 7 \\
\hline Zrenjanin $^{a}$ & Serbia & 1963 & 40 & 7 \\
\hline Tanushimaru $^{a}$ & Japan & 1964 & 24 & 7 \\
\hline Ushibuka $^{a}$ & Japan & 1971 & 8 & 4 \\
\hline
\end{tabular}

Note. The full cohorts contained 502 to 2571 men, of whom a random sample or 849 recorded their food intake.

${ }^{\text {a }}$ Food recorded as amounts of raw products.

${ }^{\mathrm{b}}$ Original records no longer available.

cially fruits and vegetables, from food balance sheets of Greece from the period 1961 1965 (FAO, 1984).

\section{Food Composites}

In 1986, the food intake data were recoded in a standardized way by one dietician. We converted amounts of prepared into amounts of raw foods, taking into account 


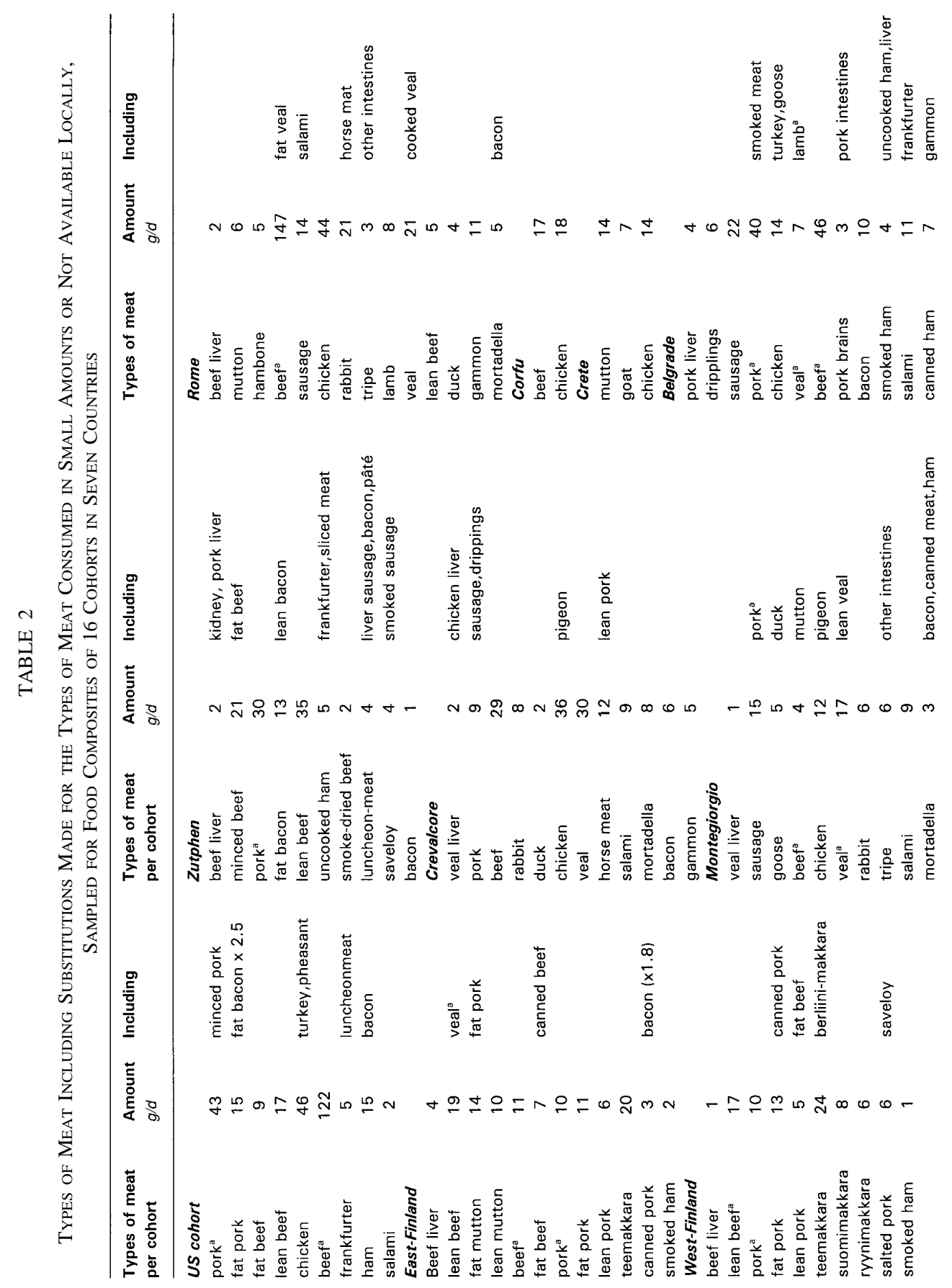




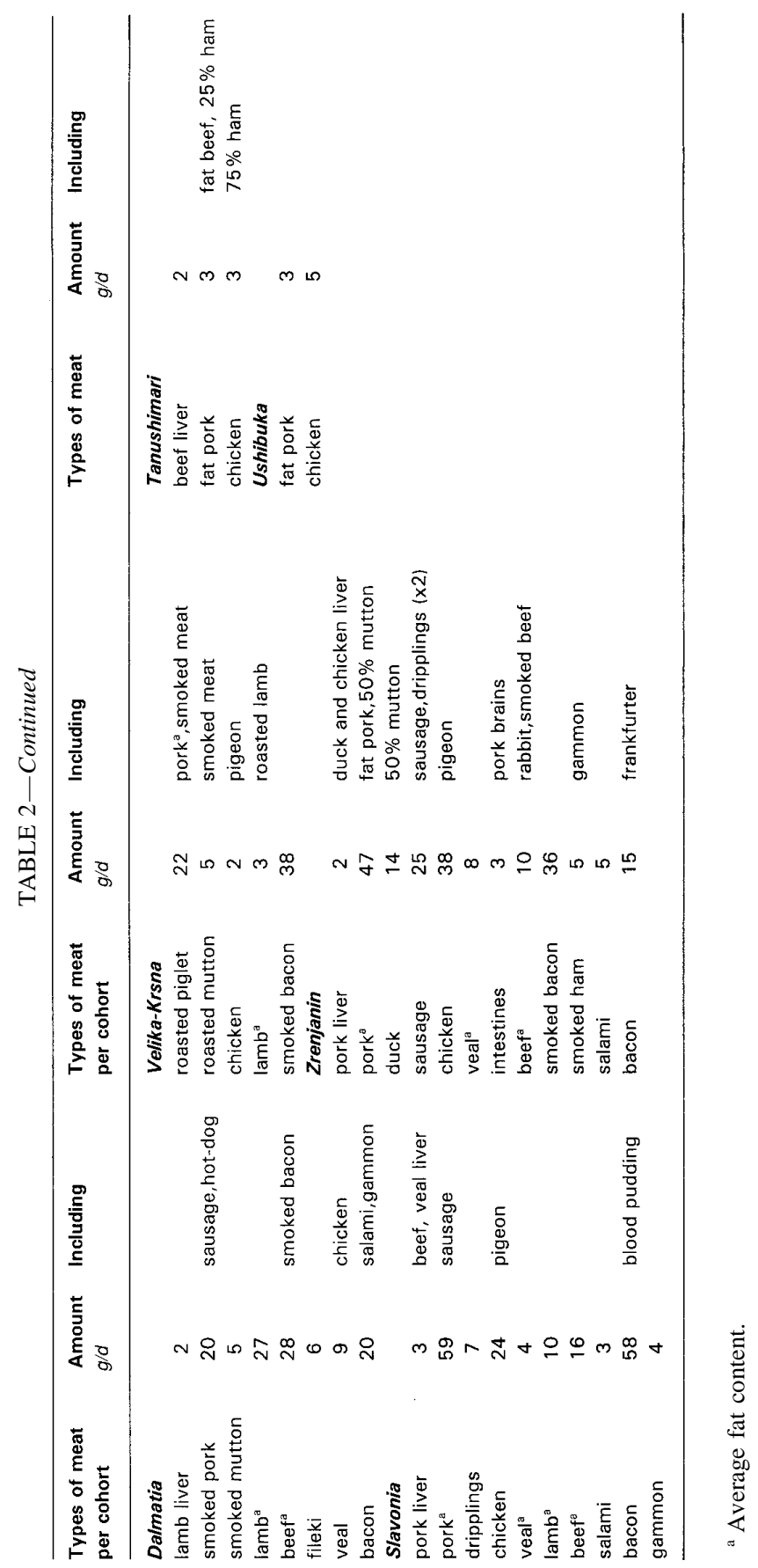


loss of water and loss and gain of fat during cooking. For each cohort sample, we averaged the daily consumption of each food across persons and collected this amount.

Two Dutch dieticians assisted by local researchers and co-workers from the Seven Countries Study bought all foods between April and October of 1987 in the same regions in which the men were living during the baseline survey in the 1960s. In 10 of the 16 locations they bought the duplicates in the same season ( \pm 2 months) during which the food intakes had been recorded. For the United States, Belgrade, Zrenjanin, and Tanushimaru the purchasing of the foods took place in a different season.

The fat compositions of foods have changed between the 1960s and 1987 (FAO, 1994), and therefore we had to select the food items carefully to approximate the composition of the foods as consumed by the men in the 1960s as near as possible. For this purpose, we used food composition tables and data from the literature (Den Hartog et al., 1968). The major food groups contributing to the fat composition of the diets were meat, dairy products, edible fats, and pastries. For meat, we often chose the fatter variants (Table 2). We reduced the quantity of products to be bought by combining foods. We substituted foods consumed in amounts of less than $10 \mathrm{~g}$ per day by foods consumed in higher amounts, with a similar nutrient composition. In Table 2, we show the substitutions made for meat. If a food was no longer available locally, we also used a substitute with a comparable composition. Detailed information on the food sampling has been described in a Dutch report (Jansen et al., 1989). The maximum number of different foods bought per cohort was 80 . The dieticians vacuumpacked all foods in plastic bags and sent them to the Netherlands in cooled boxes by air express.

The average period between acquiring the foods and their first workup in the laboratory was 2 days (range 1-4 days). Inedible parts were removed so as to produce the edible part as recorded and consumed in the 1960s. For example, we only peeled apples if that is how they were consumed originally. Thereafter, the foods were weighed out and homogenized at the Department of Human Nutrition, Agricultural University Wageningen. Foods were divided into subsamples before homogenizing. Homogeneous foods present in relatively big amounts were blended together into a main sample after addition of tBHQ $(500 \mathrm{mg} / \mathrm{kg})$. Nonhomogeneous foods or products present in small amounts were blended into a subsample first. The sizes of these subsamples were scaled up 5-50 times from the original amount. After that a proportional amount of the subsample was added separately to a part of the main sample. Foods containing vitamin $\mathrm{C}$ were also blended in separate subsamples containing $2 \%$ oxalic acid. If a sample was too dry to homogenize, a known amount of demineralized water was added. After homogenization, the final combined samples were stored at $-20^{\circ} \mathrm{C}$.

\section{Chemical Analyses}

We determined the amount of total fat according to Folch et al. (1957). The fatty acids were assayed after saponification of the Folch extract and derivatization to methyl esters (Metcalfe et al., 1966). Fatty acids were analyzed by three different methods, on a Chrompack 438AS gas chromatograph equipped with a flame ionization detector. For determination of C8, C10, C12, C14, C14:1, C15, C16, C16:1, C17, $\mathrm{C} 17: 1, \mathrm{C} 18, \mathrm{C} 18: 1, \mathrm{C} 18: 2, \mathrm{C} 18: 3(n-6), \mathrm{C} 18: 3(n-3), \mathrm{C} 20, \mathrm{C} 20: 1$, and C20:2, the column was a Durabond-225 fused silica, length $\times$ internal diameter $15 \mathrm{~m} \times 0.54 \mathrm{~mm}$. The 
flow rate of the carrier gas hydrogen was $7.5 \mathrm{ml} / \mathrm{min}$. The oven temperature was programmed from 100 to $180^{\circ} \mathrm{C}$ at a rate of $10^{\circ} \mathrm{C} / \mathrm{min}$, then to $225^{\circ} \mathrm{C}$ at $4^{\circ} \mathrm{C} / \mathrm{min}$, which was maintained for a further $2.75 \mathrm{~min}$ before cooling. The injector temperature was $220^{\circ} \mathrm{C}$, and $0.5 \mu \mathrm{l}$ was injected directly into a modified liner. The detector temperature was $250^{\circ} \mathrm{C}$, the hydrogen flow for the detector was reduced to $17.5 \mathrm{ml} / \mathrm{min}$, and the flow rate of the make-up gas nitrogen was $25 \mathrm{ml} / \mathrm{min}$.

Trans fatty acids were determined by gas chromatography in our laboratory, and these results were checked by gas chromatography and Fourier transform infrared spectrometry in the research laboratory of the Raisio group at Raisio, Finland. The trans fatty acid content of the food composite of Zutphen could not be analyzed in Finland due to solvent in the sample, and therefore it was reanalyzed by Fourier transform infrared spectrometry in our own laboratory together with the food composites of east and west Finland and Velika-Krsna.

The geometric and positional isomers of C16:1, C18:1, and C18:2 fatty acid methyl esters were measured using a CP-Sil88 fused silica $50-\mathrm{m} \times 0.25-\mathrm{mm}$ column (Chrompack, the Netherlands). The oven temperature was programmed from 160 to $220^{\circ} \mathrm{C}$ at a rate of $2^{\circ} \mathrm{C} / \mathrm{min}$ plus $5 \mathrm{~min}$ at $220^{\circ} \mathrm{C}$. The carrier gas was hydrogen, and the inlet pressure was $130 \mathrm{kPA}$. The injector was a splitter with a split ratio of 1:60, and a volume of $0.5 \mu \mathrm{l}$ was injected at a temperature of $250^{\circ} \mathrm{C}$. Fourier transform infrared spectrometry in Wageningen was done using a Bio-Rad Digilab Division, Type FTS7 infrared spectrophotometer. The preparation of fatty acid methyl esters for gas chromatography in Finland was done according to Bannon et al. (1982), and for the infrared spectrometry method according to IUPAC 2.301. Duplicate esters of the samples were analyzed as neat solutions according to Sleeter and Matlock (1989). For gas chromatography in Finland a Hewlett-Packard 5890 II was used, and the IR spectrophotometer was a Perkin-Elmer 16PC, Type FTIR.

The fatty acids C18:4(n-3), C22, C22:1(n-9), C20:3(n-3), C20:4(n-6), C24, C20:5(n3), C24:1, C22:3(n-3), C22:4(n-6), C22:5(n-3), and C22:6(n-3) were assessed separately in a third analysis, again using a CP-Sil88 fused silica $50-\mathrm{m} \times 0.25-\mathrm{mm}$ column. The initial oven temperature was $160^{\circ} \mathrm{C}$ for $4 \mathrm{~min}$, followed by a rise of $25^{\circ} \mathrm{C} / \mathrm{min}$ to $215^{\circ} \mathrm{C}$, which was kept for a further $12 \mathrm{~min}$ before cooling down. The injector was a Splitter with a split ratio of 1:15, and the injected volume was $1.5 \mu$ l. Injector and detector temperature were $250^{\circ} \mathrm{C}$.

We extracted the unsaponifiable part of the lipid (Association of Official Analytical Chemists, 1984) and determined cholesterol, campesterol, stigmasterol, and $\beta$-sitosterol by gas chromatography using a Chrompack-Packard Model 439 column CP$\mathrm{Si} 119 / \mathrm{cb}(25 \mathrm{~m} \times 0.25 \mathrm{~mm})$. The oven temperature was programmed from 240 to $265^{\circ} \mathrm{C}$ at a rate of $1.25^{\circ} \mathrm{C} / \mathrm{min}$, then to $285^{\circ} \mathrm{C}$ by $5^{\circ} \mathrm{C} / \mathrm{min}$, which was maintained for a further $8 \mathrm{~min}$ before cooling down. The carrier gas hydrogen had an inlet pressure of $105 \mathrm{kPa}$. The injector was a splitter, and the injected volume $1 \mu \mathrm{l}$ with a split ratio of 1:30. The temperature of injection was $300^{\circ} \mathrm{C}$ and of detection $305^{\circ} \mathrm{C}$. The flow rate of the make-up gas nitrogen was $25 \mathrm{ml} / \mathrm{min}$. We determined response factors by injection of pure compounds with $5 \alpha$-cholestane as internal standard. For campesterol we used the factor for cholesterol. Chromatograms for fatty acids and for sterols were recorded by a personal computer equipped with PCI-GC software Version 4.0 (Chrompack).

We tested the recovery of $n-3$ fatty acids by adding herring of known EPA and 
DHA content to $1766 \mathrm{~g}$ of the food composite of Zutphen. Recovery was $106 \pm 5 \%$ for $\mathrm{C} 20: 5$ and $98 \pm 6 \%$ for $\mathrm{C} 22: 6$ after addition of $11 \mathrm{~g}$, and $93 \pm 5 \%$ for $\mathrm{C} 20: 5$ and $88 \pm 4 \%$ for $\mathrm{C} 22: 6$ after addition of $25 \mathrm{~g}$ of herring.

The conversion factor used for fat to fatty acids was 0.956 . We determined protein (Association of Official Analytical Chemists, 1984) and alcohol (Anonymous, 1987) and calculated carbohydrates as the sum of analyzed values of galactose, glucose, saccharose, lactose, maltose, and starch. Atwater factors for the calculation of energy were $17 \mathrm{~kJ}$ (4 kcal) for protein, $37 \mathrm{~kJ}$ (9 kcal) for fat, $16 \mathrm{~kJ}(3.75 \mathrm{kcal})$ for carbohydrates, and $29 \mathrm{~kJ}$ (7 kcal) for alcohol.

\section{Calculation by Use of Food Composition Tables}

We compared the analyzed values for the food composites from the United States, Finland, the Netherlands, and Italy with values calculated using food composition tables. We used the Dutch computerized nutrient data bank (Kommissie UCV, 1985) for foods with a nutrient composition similar to that of Dutch foods and for foods containing no fat or sterols, and the food composition table of the specific countries (Rastas et al., 1989; Carnovale and Miuccio, 1989; U.S. Department of Agriculture, 1992) for the remainder.

\section{RESULTS}

\section{Energy and Total Fat}

The energy content varied from 9.6 MJ/day in the diets of the U.S. railroad employees to $15.8 \mathrm{MJ} /$ day in the Croatian cohort Dalmatia, and the fat content in the food composites from $12 \%$ of total energy in the Japanese farmers in Tanushimaru to $50 \%$ in the United States (Table 3). The ratio of polyunsaturated to saturated fatty acids varied from 0.2 for east and west Finland to 0.9 and 1.2 for Ushibuka and Tanushimaru in Japan, respectively (Table 3).

\section{Saturated Fatty Acids}

The saturated fatty acid content was low ( $<10 \%$ of energy) in the food composites of Greece and Japan, the Italian cohorts Montegiorgio and Rome, and the Croatian cohort Dalmatia. We found high levels of saturated fatty acids ( $>15 \%$ of energy) for east and west Finland, the Netherlands, the United States, the Serbian cohorts Belgrade and Zrenjanin, and the Croatian cohort Slavonia.

The levels of the medium-chain fatty acids caprylic (C8:0) and capric (C10:0) acid were high in the Finnish samples (Table 4). The contribution of lauric (12:0), myristic (14:0), and palmitic (16:0) acid varied from $65 \%$ of saturated fatty acids for Zrenjanin in Serbia to $79 \%$ for Corfu and Crete (Table 4). Stearic acid content ranged from 20 (Tanushimaru, Japan) to $32 \%$ (Zrenjanin, Serbia) of saturated fatty acids. The highest amount of saturated fatty acids of more than 20 carbon atoms was $2.5 \mathrm{~g} /$ day in Zutphen (Table 4).

\section{Monounsaturated Fatty Acids}

The range of monounsaturated fatty acids varied from $9.8 \mathrm{~g} / \mathrm{day}$ in Tanushimaru, Japan, to $84 \mathrm{~g} /$ day on the Greek isle of Crete. The levels of monounsaturated fat in the food composites of Greece exceeded $20 \%$ of energy. 


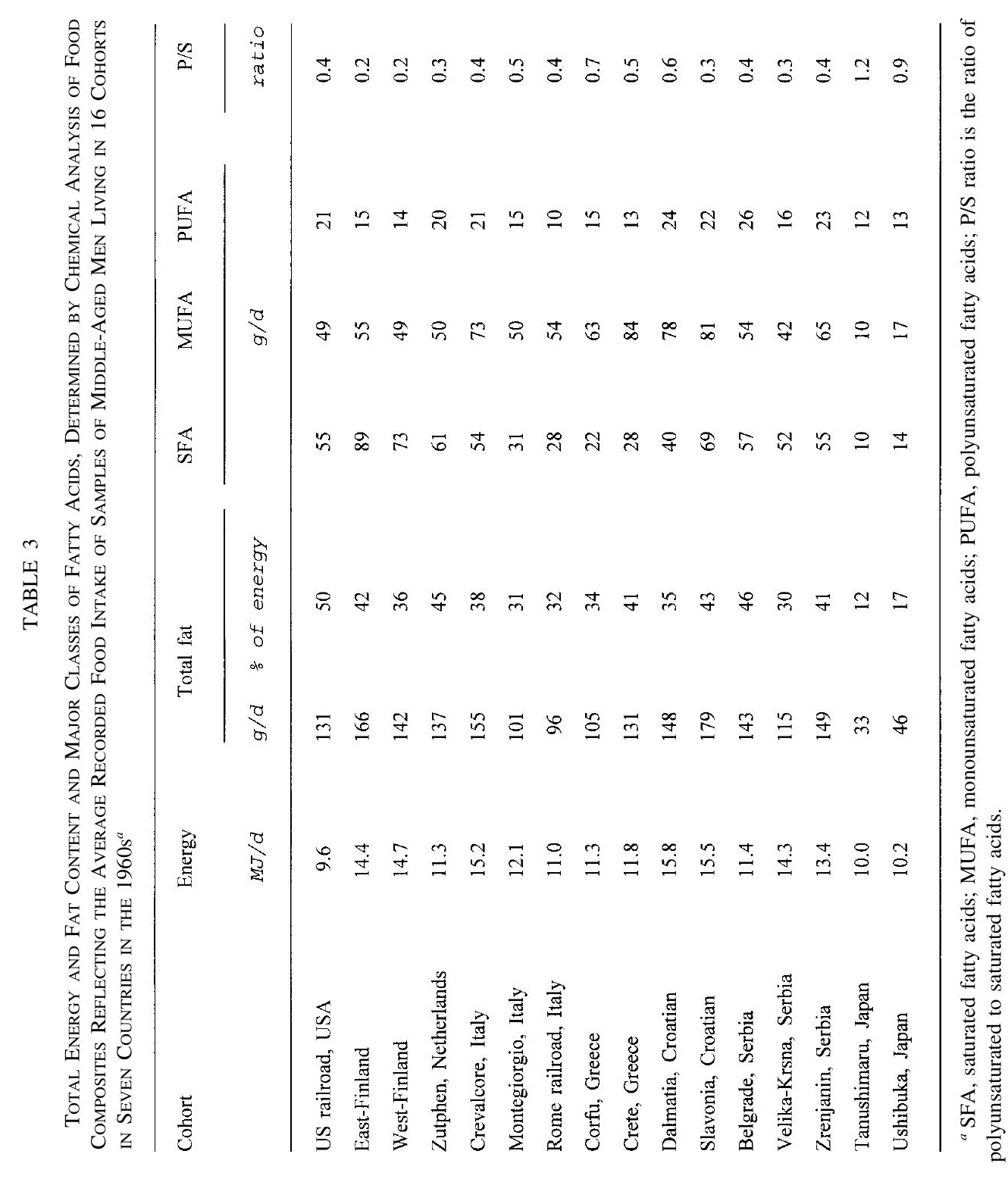




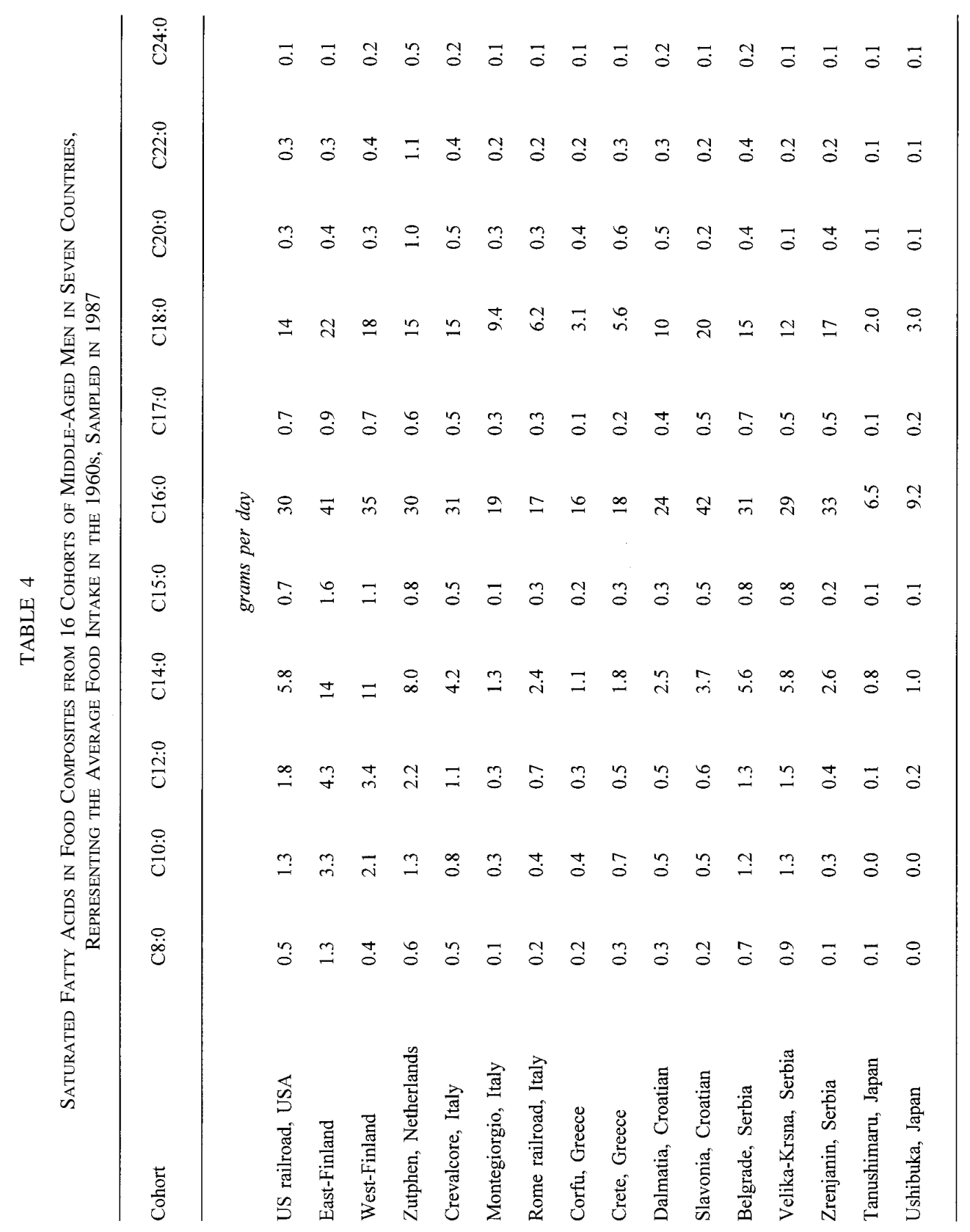




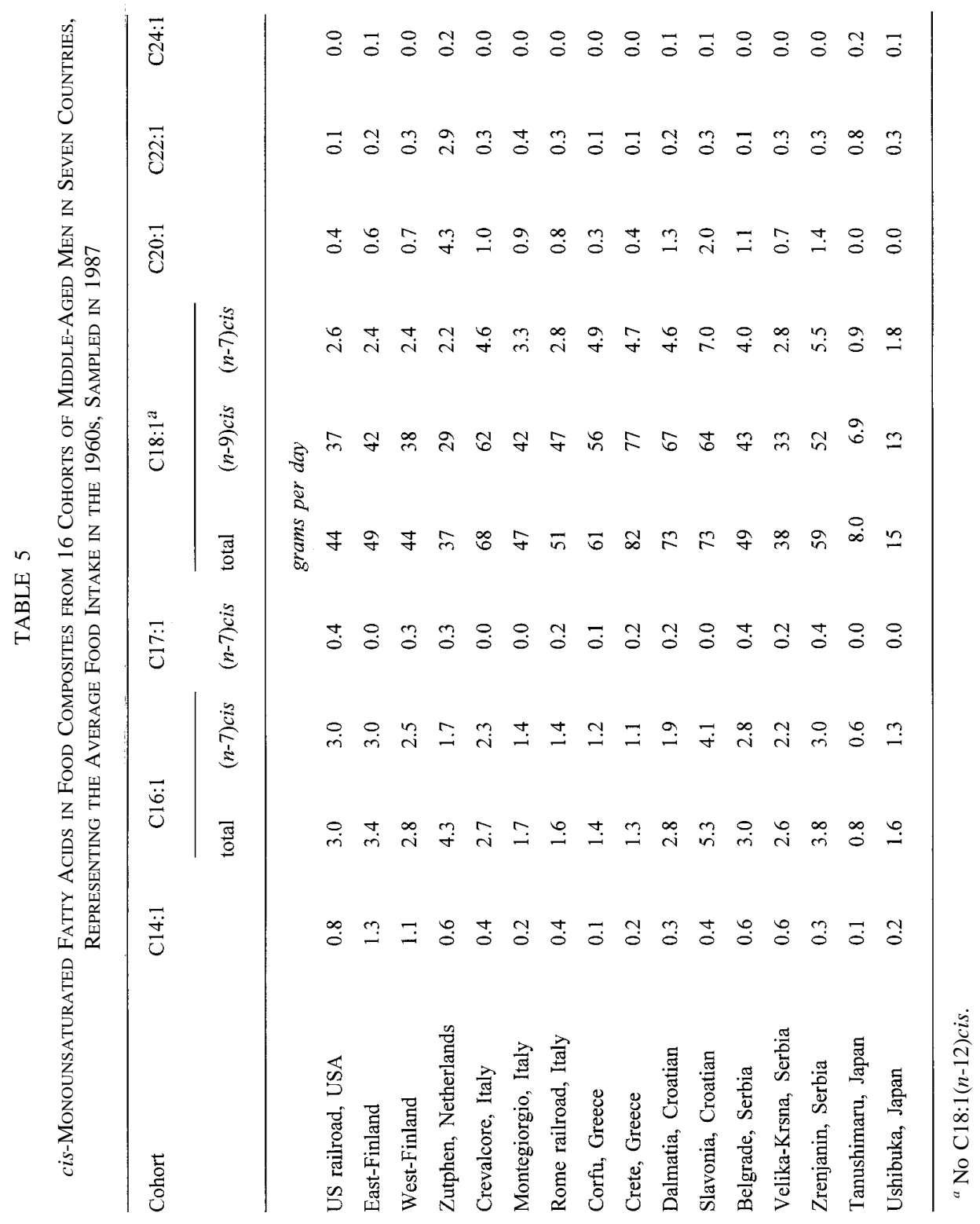


Sixty to ninety percent of monounsaturated fat (Table 5) in the food composites occurred as oleic acid [cis C18:1(n-9)]. The absolute amount varied from $8.0 \mathrm{~g} /$ day in Tanushimaru, Japan, cohort to $82 \mathrm{~g} /$ day in Crete. The second major monounsaturated fatty acid was palmitoleic acid [cis C16:1(n-7)] with a highest consumption of about $4 \mathrm{~g} /$ day in Slavonia, Croatia. The maximum intake of both erucic [C22:1(n-9)] and cetoleic acid [C22:1(n-11)] was $2.9 \mathrm{~g} /$ day in Zutphen (Table 5).

Total intake of very long chain fatty acids (saturated and unsaturated fatty acids with more than 20 carbon atoms) was about $14 \mathrm{~g} /$ day in Zutphen and $2-5 \mathrm{~g} / \mathrm{day}$ in the other cohorts (Tables 4, 5, and 6).

\section{Trans Fatty Acids}

The amount of trans fatty acids with 16 and 18 carbon atoms as determined by gas chromatography in Wageningen varied from $0.2 \mathrm{~g}$ or $0.1 \%$ of energy in Corfu, Greece, to $8.6 \mathrm{~g}$ or $2.8 \%$ of energy in Zutphen, the Netherlands (Table 6). The highest levels, absolute as well as relative to energy intake, were found in the food composites of the Dutch, U.S., and Finnish cohorts, and the lowest amounts in those of Greece, Italy, and Japan. The main contribution to trans fatty acids was formed by trans isomers of C18:1 (Fig. 1). The food composite of Zutphen contained the highest amount of trans isomers of palmitoleic acid (16:1), while trans 16:1 was not present in the food composites of Italy, Greece, Croatia, and Zrenjanin, Serbia. The values measured in Finland by gas chromatography were on average $0.4 \pm 0.9 \mathrm{~g} /$ day lower than in Wageningen. The value for Zutphen, Netherlands, was $3.5 \mathrm{~g} /$ day higher while differences for other cohorts were less than $1 \mathrm{~g} /$ day. The total amount of trans fatty acids as assessed by infrared spectrometry was in general higher than the amounts of 16:1, 18:1, and 18:2 trans fatty acids assessed by gas chromatography (Fig. 2). We found a large difference between the methods for the Zutphen cohort.

\section{Polyunsaturated Fatty Acids}

The polyunsaturated fatty acid fraction (Table 7 ) consisted of 54 to $85 \%$ of linoleic acid [18:2(n-6)]. The intake of linoleic acid was high in the Serbian cohorts of Zrenjanin and Belgrade and in the United States, and low in Finland. As for the other $(n-6)$ polyunsaturates the amount of $\gamma$-linolenic acid [18:3(n-6)] was at the most $0.29 \mathrm{~g}$, and arachidonic acid [C20:4(n-6)] $0.5 \mathrm{~g}$ per day. The content of the major $n-3(\omega-3)$ polyunsaturated fatty acid, $\alpha$-linolenic acid, varied from $0.79 \mathrm{~g}$ in the diet of Rome railroad workers to $2.5 \mathrm{~g}$ per day in east Finland. The food composites of Japan, Dalmatia, east Finland, and Corfu contained the highest and those of the United States, Rome, and Velika-Krsna the lowest levels of eicosapentaenoic [EPA; C20:5(n-3)] and docosahexanoic acid [DHA; C22:6(n-3); see Fig. 3 ). The ratio of linoleic to $\alpha$-linolenic acid ranged from 3.2 in east Finland to 15 in Velika-Krsna (Table 7).

The $(n-3)$ fatty acids have critical roles in membrane structure and are precursors of eicosanoids in the body. A number of studies have shown that the consumption of foods containing EPA and DHA is associated with decreased risk of coronary heart disease (Katan, 1995). $\alpha$-Linolenic acid is elongated in the body to EPA and DHA, and the efficiency of this conversion is estimated to be about $20 \%$ (Emken 


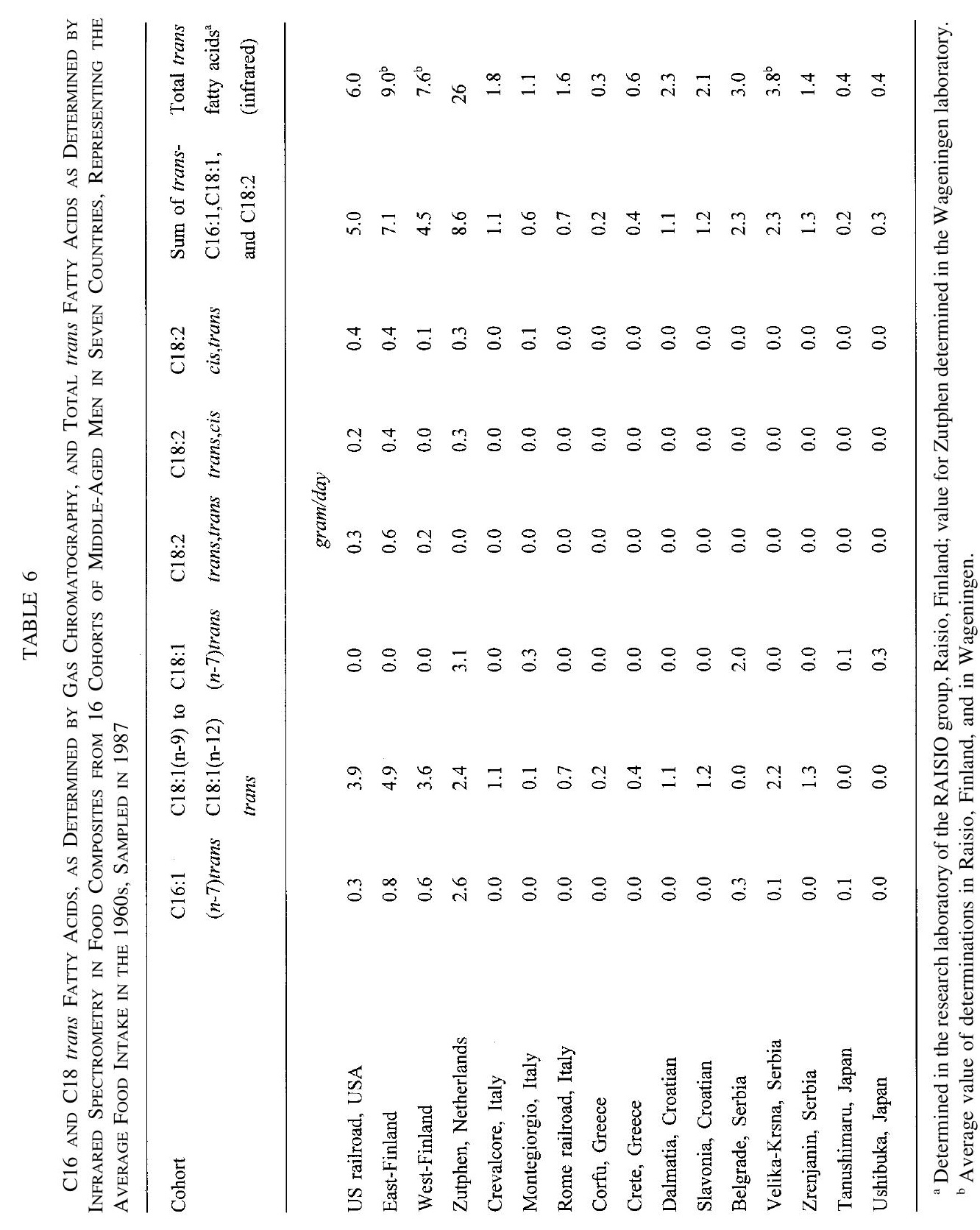




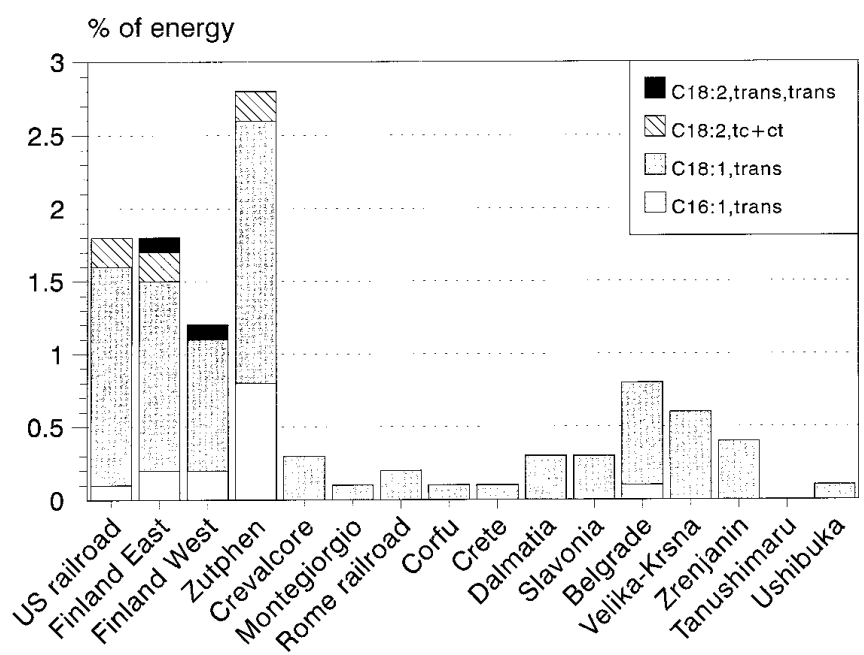

FIG. 1. The amount of C16:1, C18:1, and C18:2 trans fatty acids according to gas chromatography in food composites from 16 cohorts of middle-aged men in seven countries, representing the average food intake in the 1960s, sampled in 1987.

et al., 1992). Therefore, $1 \mathrm{~g}$ of dietary $\alpha$-linolenic acid is not equivalent physiologically to $1 \mathrm{~g}$ of EPA or DHA but to much less. In order to allow comparison of the total intake of $(n-3)$ fatty acids across cohorts independent of source we multiplied $\alpha$-linolenic acid intake by 0.2 and combined these values with intakes of EPA and

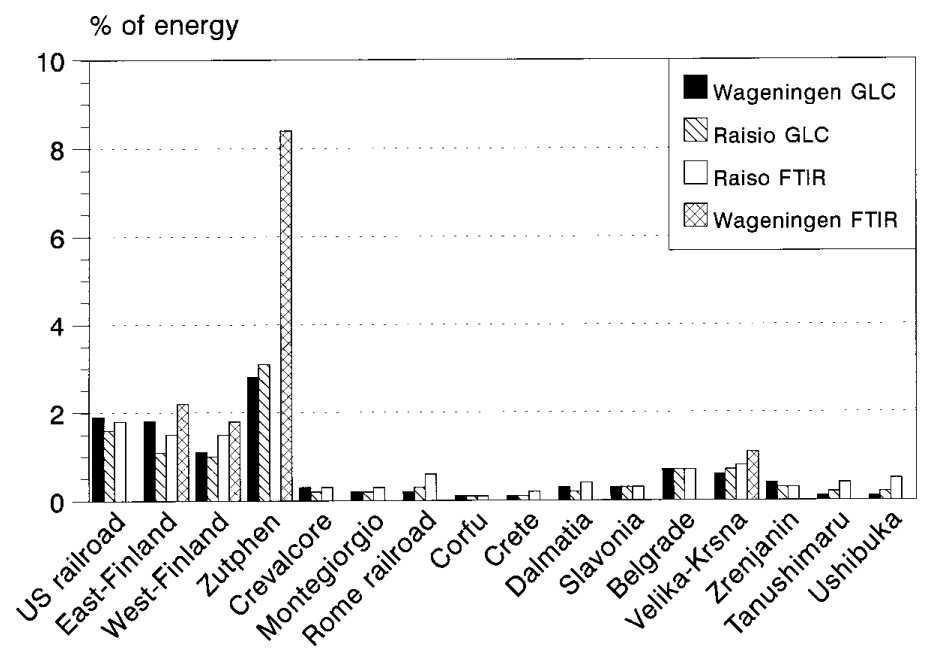

FIG. 2. Sum of C16:1, C18:1, and C18:2 trans fatty acids according to gas chromatography in Wageningen and Raisio, Finland, and total trans fatty acids including C20 and C22 isomers according to infrared spectometry in Raisio, Finland, in food composites from 16 cohorts and according to infrared spectrometry in Wageningen from 4 cohorts of middle-aged men in seven countries, representing the average food intake in the 1960s, sampled in 1987. 


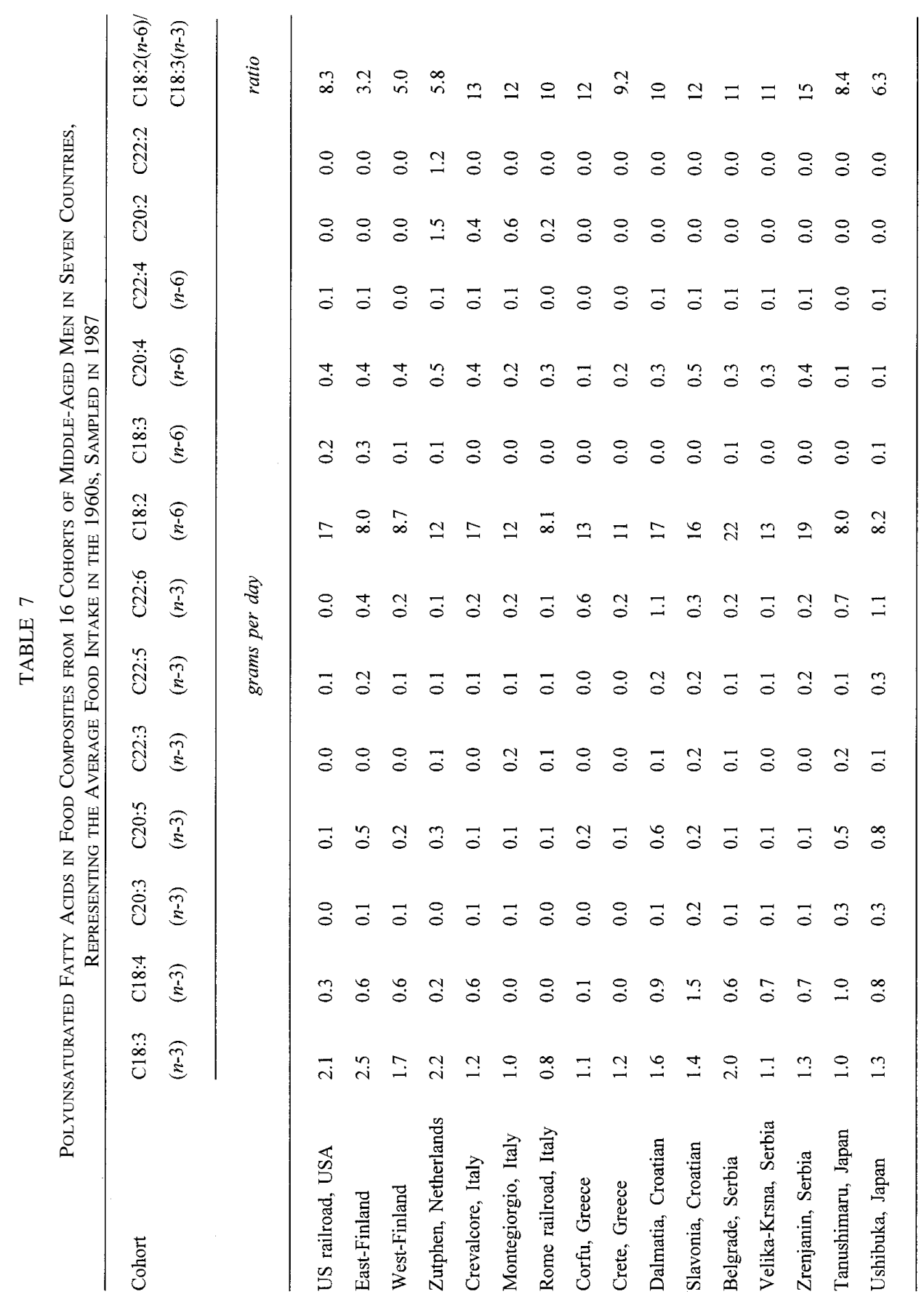




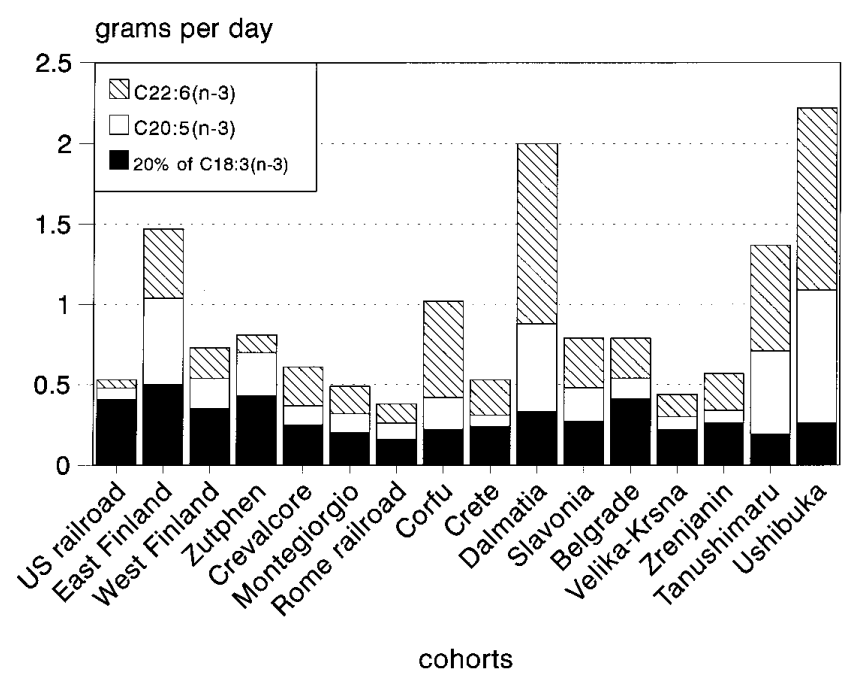

FIG. 3. The amount of the major (n-3) fatty acids in food composites from 16 cohorts of middle-aged men in seven countries, representing the average food intake in the 1960s, sampled in 1987, including $20 \%$ of the intake of $\mathrm{C} 18: 3(n-3)$, as a measure for C18:3(n-3) converted into longer ( $n-3)$ fatty acids in the body. Values for C18:3 were divided by 5 because only about one-fifth of dietary C18:3 is elongated to EPA or DHA (Emken et al., 1992).

DHA (Fig. 3). The total intake of (n-3) fatty acids calculated in this way was highest in Ushibuka, Dalmatia, Tanushimaru, and east Finland (Fig. 3).

\section{Sterols}

The amount of cholesterol varied from $170 \mathrm{mg}$ per day in Tanushimaru to $612 \mathrm{mg}$ in Slavonia (Table 8). Intakes of plant sterols were lowest in the United States and highest in Greece. The amounts of campesterol varied from 41 (Slavonia) to $63 \mathrm{mg}$ per day (east Finland), of stigmasterol from 9 (Finland and Rome) to $30 \mathrm{mg}$ per day (Tanushimaru), and of sitosterol from 113 (U.S. railroad) to $281 \mathrm{mg}$ per day (Corfu).

\section{Sources of Visible Fats}

The visible fats as reported in the food records (Table 9) contributed from 9.7 to $72 \%$ of the total amount of fat. The main source of visible fats in the U.S. and Finnish samples in the 1960s was butter. In the Dutch sample (Zutphen), margarine was more important than butter. Lard consumption was highest in the villages from Italy and the former Yugoslavia. The only visible fat eaten in the Greek cohorts was olive oil which was also an important fat source in Montegiorgio, Rome, and Dalmatia. In Belgrade the major visible fat was sunflower oil. The Japanese used small amounts of rapeseed (Tanushimaru) or peanut oil (Ushibuka).

\section{Comparison with Food Composition Tables}

The largest difference between the calculated and the chemically determined amounts of total fat was $9 \%$ of energy or $40 \mathrm{~g}$ per day for Crevalcore (Table 10). For 


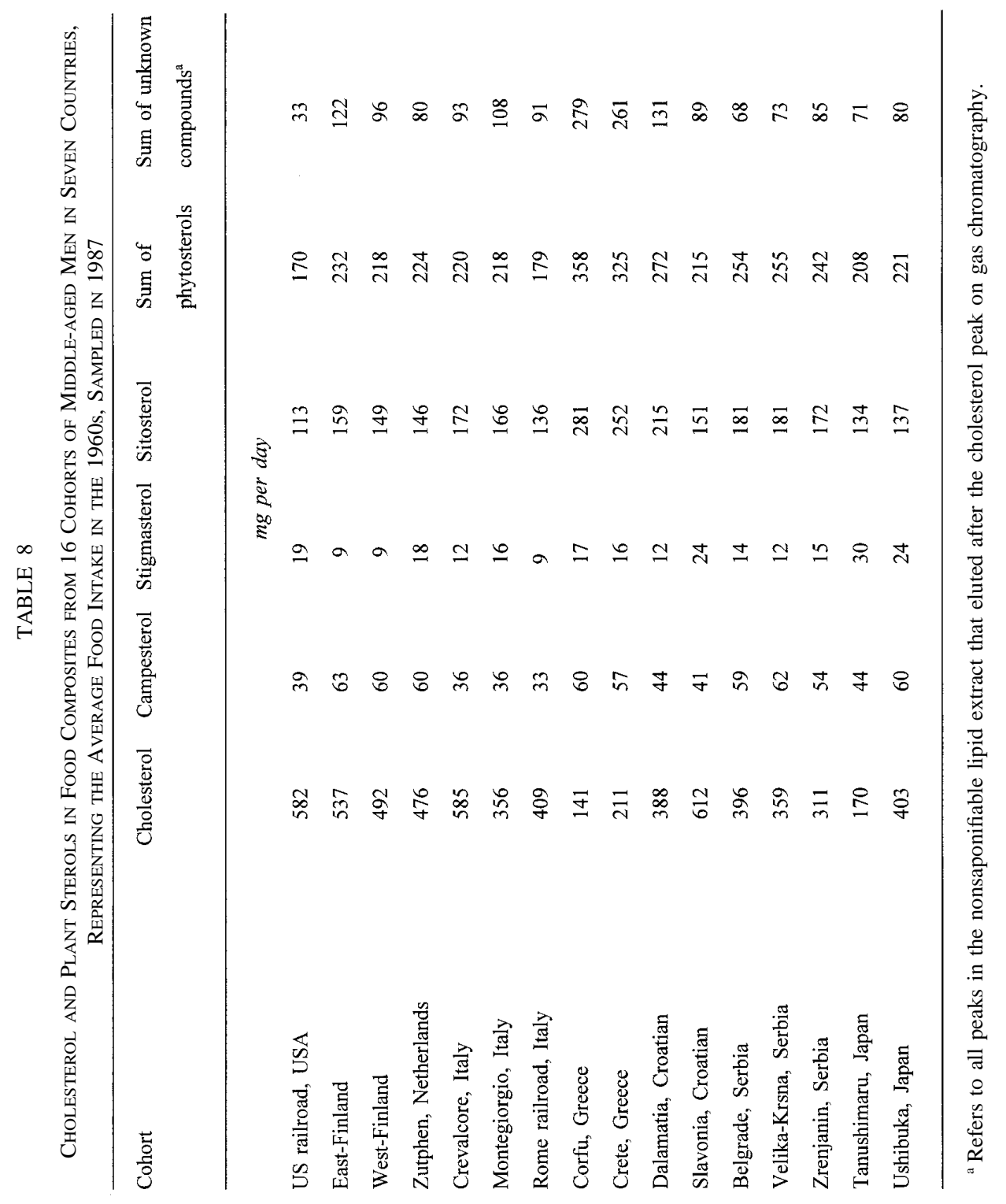


TABLE 9

Type and Amount of Visible Fats Reported in Food Records in the 1960s By Middle-Aged Men Living in 16 Cohorts in Seven Countries

Cohort

Butter Margarine Lard Olive oil Sunflower oil Other

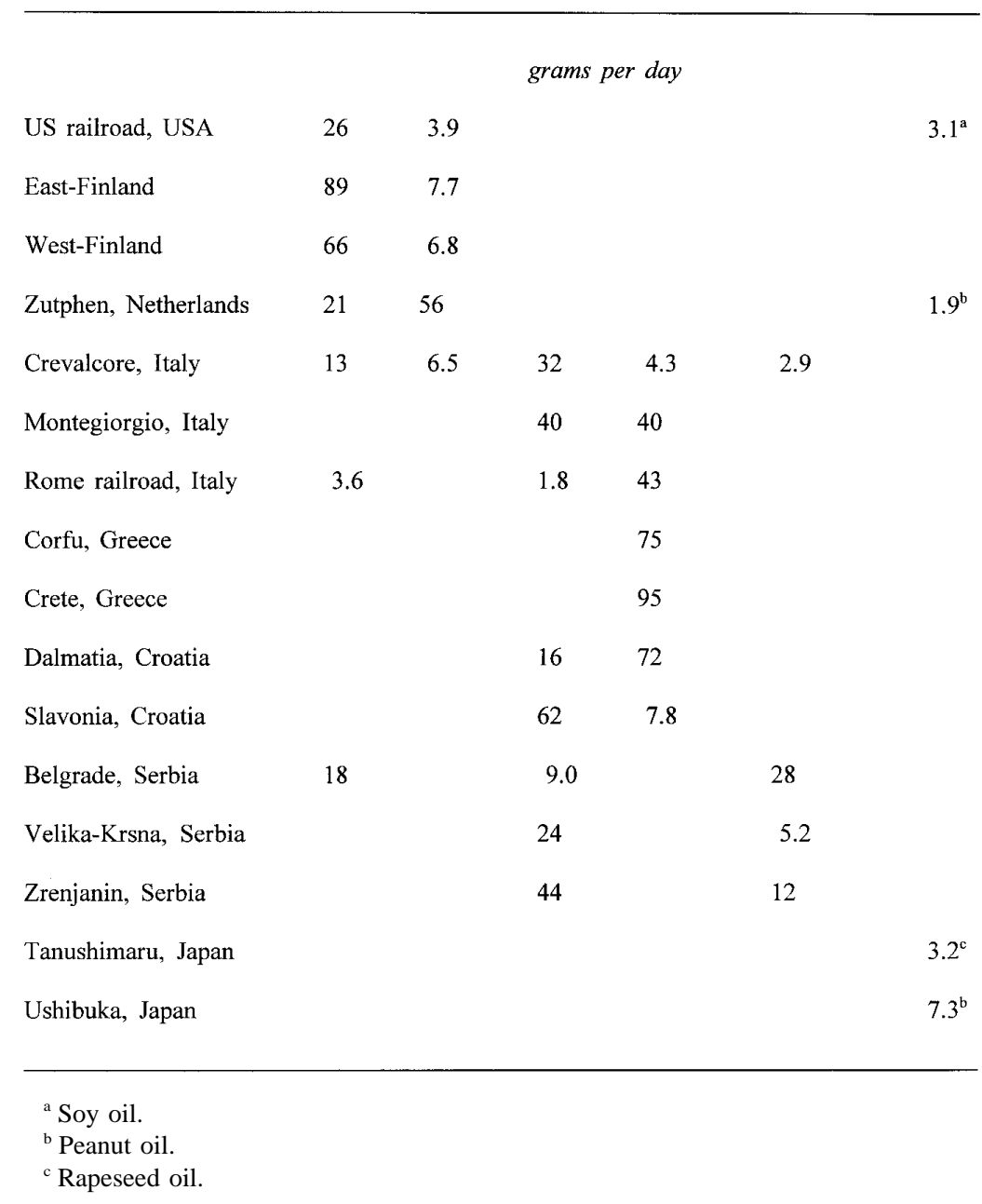

the other cohorts the difference varied from 0.1 to $3 \%$ of energy. The largest difference for saturated fat was $3.5 \%$, for monounsaturated fatty acids $4 \%$, and for polyunsaturated fat $1.6 \%$ of energy. The difference between calculated and chemically determined cholesterol was at the most $6 \mathrm{mg} / \mathrm{MJ}$ or $21 \mathrm{mg} /$ day (Table 10).

\section{DISCUSSION}

We found large differences in the amounts of total fat, fatty acids, and sterols between the seven countries and between cohorts in the same country. The difference 


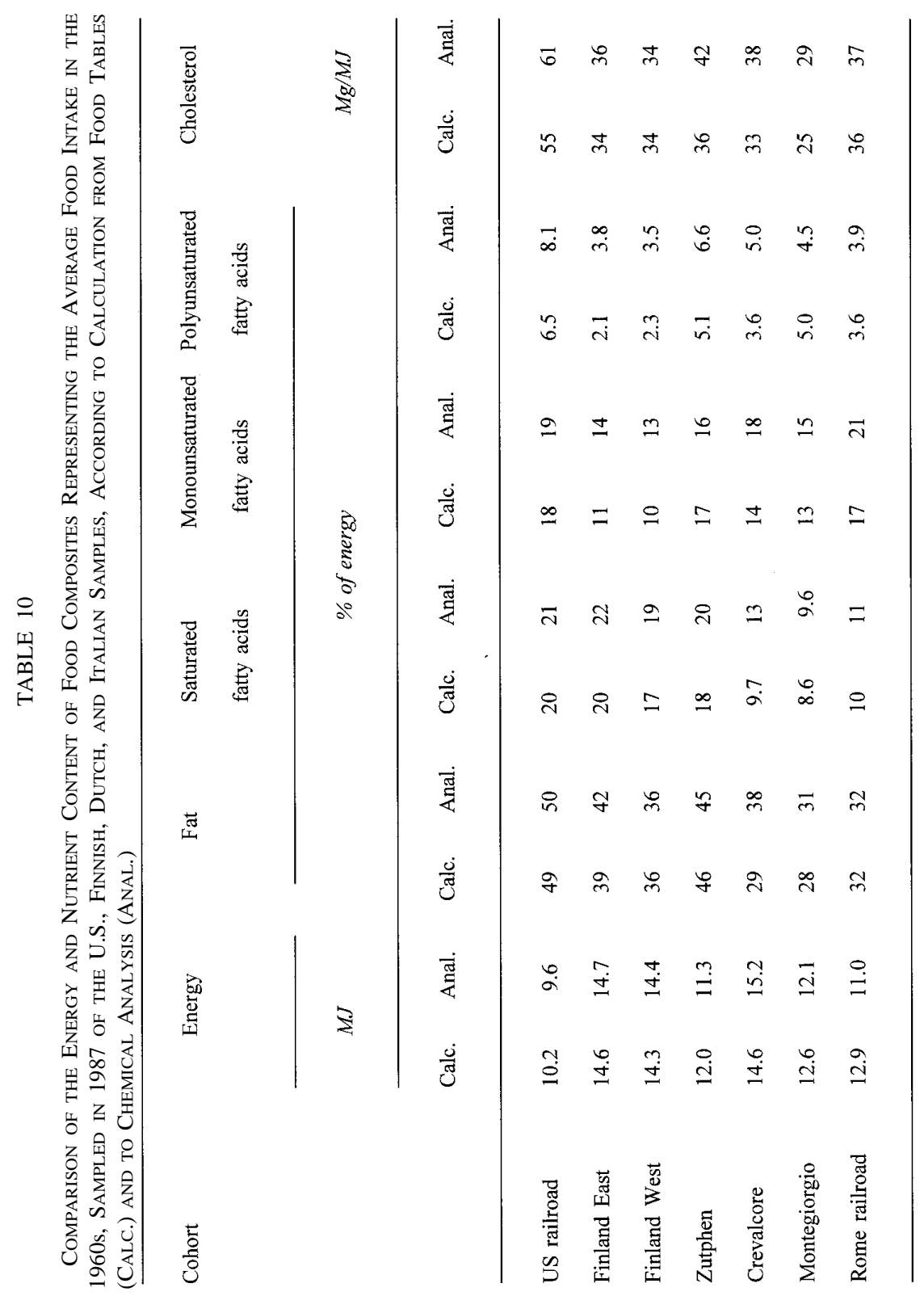


between the highest and the lowest value for trans fatty acids in food composites was $8 \mathrm{~g}$ per day ( $2.8 \%$ of energy) for those trans fatty acids detectable by gas chromatography, and 25 g per day (8.3\% of energy) for the total amount of trans fatty acids as detected by infrared spectrometry. The sum of the long-chain (n-3) fatty acids, EPA and DHA, between the highest and the lowest value differed by almost $2 \mathrm{~g}$ per day. Amounts of fish providing these or smaller amounts of EPA and DHA are associated with marked differences in coronary heart disease incidence. Most differences can be explained by the differences in food intake, e.g., higher intakes of hydrogenated fats and milk resulted in higher trans fatty acids levels, and higher fish consumption resulted in a higher EPA plus DHA content of the food composites.

Two important questions are: (i) whether chemical analysis of food composites based on food records and composed 30 years after food recording provided valid data and (ii) to what extent the results of samples may be extrapolated to the full cohorts and to their respective countries.

\section{Food Records}

We selected the amounts and types of foods for composing the food composites on the basis of food records from the 1960s. Weighed food records give an average underestimation of energy intake of some 10\% (de Vries et al., 1994), but they still remain the most accurate method of dietary assessment (Bingham et al., 1995). Body mass index, age, and gender appear to be the major factors associated with underreporting (Black et al., 1993; Jörgensen, 1992; Schoeller et al., 1990), although some studies did not find an effect of obesity (Bandini et al., 1990; Lissner et al., 1989). However, obese men in the Zutphen cohort reported a lower energy and fat intake than their lean counterparts (Kromhout, 1983). Therefore, the energy and fat content of the food composites of Rome, Belgrade, Crevalcore, and U.S. railroad, where the men with the highest relative body weights lived (body mass index $>25$ ), might have been underestimated more than in the other cohorts. Nevertheless, the proportional contribution of fat, fatty acids, and sterols might be still reasonably correct, so that the data of these cohorts are still valuable. Gender and age range did not differ between the cohorts.

The reconstructed data of Greece appear to be useful, as they result in a total fat composition for Crete and Corfu that agrees with that reported earlier (Sasaki et al., 1993). Although we derived the food composite of the United States from only 1-day records, it can still be considered representative for the food intake of the cohort, because food records of 30 men were used. It is uncertain if the 8 Ushibuka men were representative of the men in their cohort, but as the total fat level of the food composite agrees with other data of Japanese dietary surveys (Sasaki et al., 1993; FAO, 1994), they probably were.

We do not expect that seasonal variation had a large effect on the results of our study. Seven-day surveys covered seasons of the year, and the intake of energyyielding nutrients was relatively constant throughout the year (Keys, 1970).

\section{Food Sampling}

Most foods to be collected for the food composites were available. We acquired them within 5 months and sampled the foods for all cohorts in the same way. All 
food composites were analyzed in one laboratory. Although the relative positions of the cohorts in the distribution of different foods between 1961-1965 and 1975-1977 were maintained (Kromhout et al., 1989), foods probably have changed in their total fat, fatty acid, and sterol composition between the 1960s and the 1980s (FAO, 1994). Meat and dairy products with the same total fat content as recorded by the men were largely still available. We only selected margarines of the stick form made from the same hydrogenated oils as in the 1960s. The main edible fat was margarine only in Zutphen, and as we periodically monitor the fat composition of Dutch margarines (Hulshof et al., 1991), it was possible to choose a margarine with a highly similar fatty acid composition in 1987.

In the 1960s, chemical analysis for determination of a limited number of nutrients of equivalent composites provided the amount of saturated, monounsaturated, and polyunsaturated fatty acids for 13 of the 16 cohorts (Keys, 1970; Den Hartog et al., 1968). The correlation coefficients between these determinations and those found in our study for the same cohorts were $0.92(P<0.001)$ for saturated fatty acids, 0.95 $(P<0.0001)$ for monounsaturated fatty acids, and $0.65(P<0.02)$ for polyunsaturated fatty acids. Therefore, we apparently succeeded in selecting the right foods and in composing representative food composites.

\section{Chemical Analysis}

We were not able to assess butyric (C4:0) and caproic (C6:0) acids, due to workup of the samples and the method used for gas chromatography. Butyric and caproic acid contribute about $5 \%$ of total fatty acids in dairy products (Gurr, 1992). We calculated that as a result we could have missed at most about $3 \mathrm{~g}$ of fat per day in the cohorts with a high consumption of dairy products.

We considered the methods used well validated for food composites with more than $5 \%$ of fatty acid methyl esters. We used internal quality control samples, and within and between variations of determinations of these samples were respectively 1.4 and $1.7 \%$ for total fat (mean $18 \mathrm{~g}, n=20$ ), 1.4 and $2.0 \%$ for C16:0 (mean $34 \mathrm{~g}$, $n=64$ ), 2.9 and $3.6 \%$ for C18:0 (mean $5.2 \mathrm{~g}, n=64$ ), and 1.8 and $2.4 \%$ for C18:2 (mean $15 \mathrm{~g}, n=64$ ).

Comparisons between trans fatty acid levels between assessment by gas chromatography and Fourier transform infrared spectrometry performed in the two laboratories showed good agreement, except for the Zutphen cohort which contains C20 and C22 polyunsaturated fatty acids in the trans configuration.

The recovery test for detection of $(n-3)$ fatty acids showed that very small amounts of C20:5(n-3) and C22:6(n-3) could be determined accurately in the food composites. From all this it appears that our data are valid estimates of the fatty acid and sterol composition of the diets.

\section{Calculation by Use of Food Composition Tables}

The results of calculation by use of food composition tables agreed well with those of chemical analyses, except for the high fat content of the Crevalcore composite. This difference may be caused by a decrease of fat content of foods from the sixties to the eighties, although we did not find differences between calculated and analyzed fat content of this magnitude for Montegiorgio and Rome, for which we used the 
same food composition tables as for Crevalcore (Kommissie UCV, 1985; Carnovale and Miuccio, 1989). The total fat content assessed in the 1960s corresponds with the lower calculated level. This could point to selections of food with a fat content too low for this cohort. The calculations indicate that the difference in fat content was distributed evenly over the different fatty acids.

\section{Fatty Acid Composition}

Medium-chain fatty acids and stearic acid do not raise plasma low-density lipoprotein (LDL) (Keys et al., 1965; Hegsted et al., 1965; Bonanome and Grundy, 1988; Grundy, 1990; Yu et al., 1995). We found small differences in medium-chain fatty acid intake between cohorts, but stearic acid was 10 times higher in Finland and Slavonia than in Japan (Table 4). Palmitic (C16:0), myristic (C14:0), and lauric (C12:0) acid clearly raise LDL cholesterol, and therefore are considered atherogenic (Willett and Sacks, 1991; Grundy, 1990; Zock et al., 1994). Finland had the highest intakes of all three of these fatty acids, due to a high intake of butter and milk, and Tanushimaru, Japan, had the lowest.

Oleic acid in the diet shows beneficial effects on the lipoprotein risk profile for coronary heart disease (Mensink and Katan, 1989; Yu et al., 1995). Cohorts in Greece, Italy, and the former Yugoslavia, with a high consumption of olive oil, showed the highest intake of oleic acid. Long-chain monoenoic fatty acids with 20 and 22 carbon atoms occur in margarines containing partially hydrogenated marine oils. That was confirmed for the Zutphen sample, in which these fatty acids contributed $1 \%$ of energy. Erucic acid (C22:1) may cause cardiac lipidosis in rats (Gurr, 1992). The effects in humans are not clear, but toxicity is likely to be much less in a mixed diet (Gurr, 1992). A regulation in the European Community limits the erucic acid in foods to $5 \%$ of fat content. The highest amount of this fatty acid in our study, $0.9 \%$ of energy or $2 \%$ of fat content in the sample of Zutphen, was below this level. The erucic acid in Tanushimaru (Table 5) probably came from rapeseed oil.

Trans unsaturated isomers of 18:1 and 18:2 fatty acids are formed during partial hydrogenation of oils rich in linoleic and oleic acid. There is increasing evidence that these trans fatty acids raise LDL and reduce high-density lipoprotein cholesterol levels (Katan et al., 1995; Mensink and Katan, 1990; Nestel et al., 1992). Sources for trans fatty acids are dairy products, meat, and margarines, cooking fats, and shortenings made with partially hydrogenated oils (British Nutrition Foundation Task Force, 1995; Gurr, 1992; Litin and Sacks, 1993). The data for C16 and C18 trans fatty acids assessed by gas chromatography agreed well between the Finnish and the Wageningen laboratory (cf. Methods). We found higher values by using infrared spectrometry. The gas chromatography values could be an underestimation due to a partial overlap of C18:1 cis and C18:1 trans positional isomers, and because they do not include trans fatty acids of 20 carbon atoms and more. The high values for total trans fatty acids for Zutphen (Fig. 2) can be explained by a high consumption of margarines with hydrogenated fish oils. These oils contain large amounts of trans isomers with 20 or $22 \mathrm{C}$ atoms which can be detected by infrared spectrometry but not by gas chromatography. The high amount of fatty acids with more than 20 carbon atoms in the Zutphen sample (14 g/day) confirmed the presence of hardened fish oils. Also, the high C16:1(n-7) trans value for Zutphen probably originated from hydrogenated fish oils in margarines. 
Aitchison et al., (1977) determined the mean daily intake of trans fatty acids by duplicate portion analysis for 11 and van den Reek et al. (1986) for 8 American women. Total trans fatty acids relative to energy agreed well with our value for the U.S. cohort: Aitchison found $1.8 \mathrm{~g} / 1000 \mathrm{kcal}$, van Reek found $2.1 \mathrm{~g} / 1000 \mathrm{kcal}$, and we found $2.2 \mathrm{~g} / 1000 \mathrm{kcal}$. The average daily intake of trans fatty acid for the United States was estimated as $8.1 \mathrm{~g} /$ day (about $3.9 \mathrm{~g} / 1000 \mathrm{kcal}$ ) by Hunter and Applewhite (1991) and as $13 \mathrm{~g} /$ day (about $6.3 \mathrm{~g} / 1000 \mathrm{kcal}$ ) by Enig et al. (1990), as opposed to $5.0 \mathrm{~g} /$ day $(2.2 / 1000 \mathrm{kcal})$ for our sample. The estimates of Hunter and Applewhite (1991) and Enig et al. (1990) were based on disappearance and market share data, respectively, which may overestimate actual intake. Also, trans fatty acid intake could have risen between the 1960s and the 1980s as margarines replaced butter in the diet; margarines free from trans were available at that time in Europe (Katan, 1994), but not in the United States.

The trans fatty acid level determined in a representative Finnish diet in 1987 (Heinonen et al., 1992) was $1.7 \mathrm{~g} / \mathrm{day}$ or $0.7 \mathrm{~g} / 1000 \mathrm{kcal}$, while the Finnish value in our composites was $5.8 \mathrm{~g} / \mathrm{day}$ or $1.7 \mathrm{~g} / 1000 \mathrm{kcal}$. The difference could be partly explained by a decreased fat intake since the 1960s. Probably, it is even smaller in Finland nowadays, because the intake of fat has declined further, and all margarines and most vegetable fat blends have been reformulated and are very low in trans fatty acid content (Dr. Ingmar Wester, Raisio, personal communication).

The amounts of trans fatty acids in the duplicate samples of a Dutch market basket study (Van Dokkum et al., 1989, 1990) was estimated to be $10.0 \mathrm{~g} /$ day or 3.2/1000 kcal, which agreed well with our value for the Dutch cohort Zutphen $(8.6 \mathrm{~g} / \mathrm{day}$ or $3.1 \mathrm{~g} / 1000 \mathrm{kcal})$. Although both values may not be considered representative for the Dutch population, they indicate that the intake of trans fatty acids in the Netherlands remained the same between the 1960s and the 1980s.

The (n-6) and (n-3) fatty acids are essential for the formation of membranes and are precursors of eicosanoids which have a variety of functions (Leaf, 1992; GarciaClosas et al., 1993). The presence of (n-3) polyunsaturated fatty acids in the diet may reduce the risk of coronary heart disease (Leaf and Weber, 1988). Fish oils are a rich source of ( $n-3)$ fatty acids and have a high content of fatty acids with 20 or more carbon atoms. This was reflected by high contents of these fatty acids in the food composites of east Finland, the isle of Corfu in Greece, Dalmatia on the Yugoslavian coast, and Japan, which had a high fish consumption. We found differences in the intake of the (n-3) polyunsaturated fatty acids, EPA and DHA, of almost 2 g per day. Some studies suggest that the ratio between $(n-6)$ and $(n-3)$ polyunsaturated fatty acids is important in the prevention of coronary heart disease (Kinsella, 1988; FAO, 1994). Experts recommend a ratio of linoleic to $\alpha$-linolenic acid in the diet between 5:1 and 10:1 (FAO, 1994). Only 6 of the 16 cohorts met this advice (Table 5); in the other 10 cohorts the ratio was lower for 1 and higher for 9 . A problem with the use of this ratio is that $\alpha$-linolenic acid is not equivalent to longer chain $(n-3)$ fatty acids because only some $10-20 \%$ is elongated. Therefore indexes or recommendations for $(n-3)$ fatty acid should probably take into account the lower "biological value" of $\alpha$ linolenic acid relative to EPA and DHA; we have attempted to correct intake figures in this way in Fig. 3.

The values for $(n-3)$ and (n-6) polyunsaturated fatty acids in our study agreed rather well with those from earlier Finnish and Dutch studies (Heinonen et al., 1992; Van 
Dokkum et al., 1990) and corresponded with fish consumption levels of the cohorts (Kromhout et al., 1989).

\section{Sterols}

Dietary cholesterol is present in animal foods and is seen by some as an independent risk factor for coronary heart disease (Stamler and Shekelle, 1988). A cholesterol intake of less than $300 \mathrm{mg}$ per day is recommended (FAO, 1994). We found high cholesterol intakes ( $>475 \mathrm{mg}$ /day) in the U.S. railroad workers, east Finland, west Finland, Zutphen, Crevalcore, and Slavonia; these were generally due to a high intake of milk fat, eggs, and meat. Sterols in plants, phytosterols, are poorly absorbed and interfere with the absorption of cholesterol. Large intakes may lower LDL cholesterol levels (FAO, 1994). A high consumption of vegetable oils and a relative high intake of bread contributed to the high content of plant sterols in the Greek duplicates (Weihrauch and Gardner, 1978). Our results confirm previous values for plant sterol intakes of 160-360 mg per day, amounts which probably have little effect on plasma cholesterol (Vanhanen et al., 1993).

\section{Visible Fats}

Visible fats were the most important fat source in the diets. Margarine and butter were major contributors to the high saturated and trans fatty acid content of the Finnish, Dutch, and American diets, and olive oil to the monounsaturated fatty acid content of the Greek, Italian, and former Yugoslavian diet. A high consumption of lard (e.g., Slavonia) led to high intakes of total and saturated fat, but not of trans fatty acids. For the Japanese cohorts visible fats were not an important contribution to fat intake. The amounts and types of visible fats correspond with the fatty acid and sterol composition of the diets, which confirms the accuracy of our data.

\section{CONCLUSION}

We conclude that the assessment of fatty acids and sterols in the diets by chemical analysis of equivalent food composite portions is an adequate tool for estimating the average intake of subsamples of populations. However, the results of one or two cohorts do not necessarily reflect the average intake of a country.

We found large differences in the amount of total fat, fatty acids, and sterols between cohorts, which reflected the variations in food consumption patterns. Chemical analysis of equivalent food composite portions allows assessment of more fatty acids and sterols than when using food tables, so that information on the intake of less well known fatty acids and sterols can become available.

\section{ACKNOWLEDGMENTS}

We are grateful to Bennie Bloemberg, Ph.D., Esther Goddijn, R.D., Ronald Schlemper, M.D. Ph.D., and Monique Verschuren, Ph.D., for their contribution to the collection and preparation of the food composites; to Barbara Christodoulou, R.D., for help with reconstructing the Greek diets; to Dr. Ingmar Wester Raisio, Finland, and colleagues for their part of the determinations of trans fatty acids; and to J. Bos, C. GermingNouwen, and T. Kosmeyer-Schuil of the Department of Human Nutrition, Wageningen, for preparation and macronutrient analysis of the food composites. 


\section{REFERENCES}

Aitchison, J. M., Dunkley, W. L., Canolty, N. L., and Smith, L. M. (1977). Influence of diet on trans fatty acids in human milk. Am. J. Clin. Nutr. 30, 2006-2015.

Anonymous. (1987). In Methoden der Biochemischen Analytik und Lebensmittelanalytik, pp. 10-12. Boehringer Mannheim, Mannheim.

Association of Official Analytical Chemists. (1984). Official Methods of Analysis of the Association of Official Analytical Chemists. Assoc. Official Anal. Chem., Arlington, VA.

Bandini, L. G., Schoeller, D. A., Cyr, H. N., and Dietz, H. D. (1990). Validity of reported energy intake in obese and nonobese adolescents. Am. J. Clin. Nutr. 52, 421-425.

Bannon, C. D., Breen, G. J., Craske, J. D., Trong Hai, N., Harper, N. L., and O’Rourke, L. (1982). Analysis of fatty acid methylesters with high accuracy and reliability. III. Literature review of and investigations into the development of rapid procedures for the methoxide-catalysed methanalysis of fats and oils. $J$. Chromatogr. 247, 71-89.

Bingham, S. A., Cassidy, A., Cole, T. J., Welch, A., Runswick, S. A., Black, A. E., Thurnham, D., Bates, C., Khaw, K. T., Key, T. J., et al. (1995). Validation of weighed records and other methods of dietary assessment using the $24 \mathrm{~h}$ urine nitrogen technique and other biological markers. Br. J. Nutr. 73, 531550.

Black, A. E., Prentice, A. M., Goldberg, G. R., Jebb, S. A., Bingham, S. A., and Livingstone, M. B. E. (1993). Measurements of total energy expenditure provide insights into the validity of dietary measurements of energy intake. J. Am. Diet. Assoc. 93, 572-579.

Bonanome, A., and Grundy, S. M. (1988). Effect of dietary stearic acid on plasma cholesterol and lipoprotein levels. N. Engl. J. Med. 318, 1244-1248.

British Nutrition Foundation Task Force. (1995). Trans Fatty Acids. British Nutrition Foundation, London.

Carnovale, E., and Miuccio, F. (1989). Tabelle di Composizione degli Alimenti. Istituto Nazionale Della Nutrizione, Rome.

de Vries, J. H. M., Zock, P. L., Mensink, R. P., and Katan, M. B. (1994). Underestimation of energy intake by $3-\mathrm{D}$ records compared with energy intake to maintain body weight in 269 nonobese adults. Am. J. Clin. Nutr. 60, 855-860.

Den Hartog, C., Buzina, R., Fidanza, F., Keys, A., and Roine, P. (1968). Dietary Studies and Epidemiology of Heart Diseases. Stichting tot wetenschappelijke voorlichting op voedingsgebied, The Hague.

Emken, E. A., Adlof, R. O., Rohwedden, W. K., and Gulley, R. M. (1992). Comparison of linoleic and linolenic metabolism in men: Influence of dietary linoleic acid. In Essential Fatty Acids and Eicosanoids (A. Sinclair, and R. Gibson, Eds.), pp. 23-25. Am. Oil Chem. Soc., Champaign, IL.

Enig, M. G., Atal, S., Keeney, M., and Sampugna, J. (1990). Isomeric trans fatty acids in the U.S. diet. J. Am. Coll. Nutr. 9, 471-486.

FAO. (1984). Food Balance Sheets. Food and Agricultural Organisation, Rome.

FAO. (1994). Fats and Oils in Human Nutrition: Report of a Joint Expert Consultation. Food and Agriculture Organisation, Rome.

Folch, J., Lees, M., and Sloane Stanley, G. H. (1957). A simple method for the isolation and purification of total lipids from animal tissues. J. Biol. Chem. 226, 497-509.

Garcia-Closas, R., Serra-Majem, L., and Segura, R. (1993). Fish consumption, omega-3 fatty acids and the Mediterranean diet. Eur. J. Clin. Nutr. 47(Suppl. 1), S85-S90.

Grundy, S. M. (1990). Trans monounsaturated fatty acids and serum cholesterol levels. N. Engl. J. Med. 323, $480-481$.

Gurr, M. I. (1992). Role of Fats in Food and Nutrition, 2nd ed., Elsevier, London/New York.

Hegsted, D. M., McGandy, R. B., Myers, M. L., and Stare, F. J. (1965). Quantitative effects of dietary fat on serum cholesterol in man. Am. J. Clin. Nutr. 17, 281-295.

Heinonen, M., Lampi, A-M., Hyvönen, L., and Homer, D. (1992). The fatty acid and cholesterol content of the average Finnish diet. J. Food. Compos. Anal. 5, 198-208.

Hulshof, P. J. M., Van de Bovenkamp, P., Boogerd, L., Bos, J., Germing-Nouwen, C., Kosmeijer-Schuil, T. G., Hollman, P. C. H., and Katan, M. B. (1991). Voedingsmiddelenanalyses van de Vakgroep Humane 
Voeding: Deel 11 Spijsvetten en oliën. Agriculture University, Department of Human Nutrition, Wageningen.

Hunter, J. E., and Applewhite, T. H. (1991). Reassessment of trans fatty acid availability in the US diet. Am. J. Clin. Nutr. 54, 363-369.

Jansen, A. M., Kromhout, D., and Bloemberg, B. P. M. (1989). Voedingsmiddelen in het kader van de zeven-landen studie, 1985-1988. National Institute of Public Health and the Environment, Bilthoven.

Jörgensen, L. M. (1992). Who completes seven-day food records? Eur. J. Clin. Nutr. 46, 735-741.

Katan, M. B. (1994). European researcher calls for reconsideration of trans fatty acids. J. Am. Diet. Assoc. 94, 1097-1098, 1101.

Katan, M. B. (1995). Fish and heart disease. N. Engl. J. Med. 332, 1024-1025.

Katan, M. B., Zock, P. L., and Mensink, R. P. (1995). Trans fatty acids and their effects on lipoproteins in humans. Annu. Rev. Nutr. 15, 473-493.

Keys, A. (1970). Coronary heart disease in seven countries. Circulation 41(Suppl. 1), 1-211.

Keys, A. (1980). Seven Countries: A Multivariate Analysis of Death and Coronary Heart Disease. Harvard Univ. Press, Cambridge. MA.

Keys, A., Anderson, J. T., and Grande, F. (1965). Serum cholesterol response to changes in the diet. IV. Particular saturated fatty acids in the diet. Metabolism 14, 776-787.

Kinsella, J. E. (1988). Food lipids and fatty acids: Importance in food quality, nutrition, and health. Food Technol. October, 124-144.

Kommissie, U. C. V. (1985). Dutch Nutrient Data Base 1985. Voorlichtingsbureau voor de Voeding, The Hague.

Kromhout, D. (1983). Energy and macronutrient intake in lean and obese middle-aged men (the Zutphen Study). Am. J. Clin. Nutr. 37, 295-299.

Kromhout, D., Keys, A., Aravanis, C., Buzina, R., Fidanza, F., Giampaoli, S., Jansen, A., Menotti, A., Nedeljkovic, S., Pekkarinen, M., Simic, B. S., and Toshima, H. (1989). Food consumption patterns in the 1960s in seven countries. Am. J. Clin. Nutr. 49, 889-894.

Leaf, A. (1992). Health claims: Omega-3 fatty acids and cardiovascular disease. Nutr. Rev. 50, $150-154$.

Leaf, A., and Weber, P. C. (1988). Cardiovascular effects of n-3 fatty acids. N. Engl. J. Med. 318, 549557.

Lissner, L., Habicht, J. P., Strupp, B. J., Levitsky, D. A., Haas, J. D., and Roe, D. A. (1989). Body composition and energy intake: Do overweight women overeat and underreport? Am. J. Clin. Nutr. 49, 320-325.

Litin, L., and Sacks, F. M. (1993). Trans fatty acid content of common foods. N. Engl. J. Med. 329, 19691970.

Mensink, R. P., and Katan, M. B. (1989). Effect of a diet enriched with monounsaturated or polyunsaturated fatty acids on levels of low-density and high-density lipoprotein cholesterol in healthy women and men. N. Engl. J. Med. 321, 436-441.

Mensink, R. P., and Katan, M. B. (1990). Effect of dietary trans fatty acids on high-density and low-density lipoprotein cholesterol levels in healthy subjects. N. Engl. J. Med. 323, 439-445.

Metcalfe, L. D., Schmitz, A., and Pekka, J. R. (1966). Rapid preparation of fatty acid esthers from lipids for gas chromatographic analyses. Anal. Chem. 18, 514-515.

Nestel, P., Noakes, M., Belling, B., McArthur, R., Clifton, P., Janus, E., and Abbey, M. (1992). Plasma lipoprotein lipid and $\mathrm{Lp}[\mathrm{a}]$ changes with substitution of elaidic acid for oleic acid in the diet. J. Lipid Res. 33, 1029-1036.

Rastas, M., Seppänen, R., Knuts, L. R., Karvetti, R. L., and Varo, P. (1989). Nutrient Composition of Foods. Social Insurance Inst., Helsinki.

Sasaki, S., Horacsek, M., and Kesteloot, H. (1993). An ecological study of the relationship between dietary fat intake and breast cancer mortality. Prev. Med. 22, 187-202.

Schoeller, D. A., Bandini, L. G., and Dietz, W. H. (1990). Inaccuracies in self-reported intake identified by comparison with the doubly labeled water method. Can. J. Physiol. Pharmacol. 68, 941-949.

Sleeter, R. T., and Matlock, M. G. (1989). Automated quantitative analysis of isolated (nonconjugated) trans 
isomers using Fourier transform infrared spectroscopy incorporating improvements in the procedures. $J$. Assoc. Off. Anal. Chem. 66, 121-127.

U.S. Department of Agriculture. (1992). Composition of Foods. U.S. Department of Agriculture, Washington, DC.

van den Reek, M. M., Craig-Schmidt, M. C., Weete, J. D., and Clark, A. J. (1986). Fat in the diets of adolescent girls with emphasis on isomeric fatty acids. Am. J. Clin. Nutr. 43, 530-537.

Van Dokkum, W., De Vos, R. H., Dukel, F., and Hilwig, G. N. G. (1990). Analysis of macrocomponents and fatty acids in the market basket of male adolescents in the Netherlands. J. Am. Diet. Assoc. 90, $77-$ 81.

Van Dokkum, W., Kistemaker, C., and Hilwig, G. N. G. (1989). De vetzuursamenstelling van 24-uurs duplicaatvoedingen. Voeding 50, 214-218.

Vanhanen, H. T., Blomqvist, S., Ehnholm, C., Hyvönen, M., Jauhiainen, M., Torstila, I., and Miettinen, T. A. (1993). Serum cholesterol, cholesterol precursors, and plant sterols in hypercholesterolemic subjects with different apoE phenotypes during dietary sitostanol ester treatment. J. Lipid Res. 34, 1535-1544.

Weihrauch, J. L., and Gardner, J. M. (1978). Sterol content of foods of plant origin. J. Am. Diet. Assoc. 73, 39-47.

Willett, W. C., and Sacks, F. M. (1991). Chewing the fat. How much and what kind? N. Engl. J. Med. 324, $121-123$.

Yu, S., Derr, J., Etherton, T. D., and Kris-Etherton, P. M. (1995). Plasma cholesterol-predictive equations demonstrate that stearic acid is neutral and monounsaturated fatty acids are hypocholesterolemic. Am. J. Clin. Nutr. 61, 1129-1139.

Zock, P. L., de Vries, J. H. M., and Katan, M. B. (1994). Impact of myristic acid versus palmitic acid on serum lipid and lipoprotein levels in healthy women and men. Arterioscler. Thromb. 14, 567-575. 